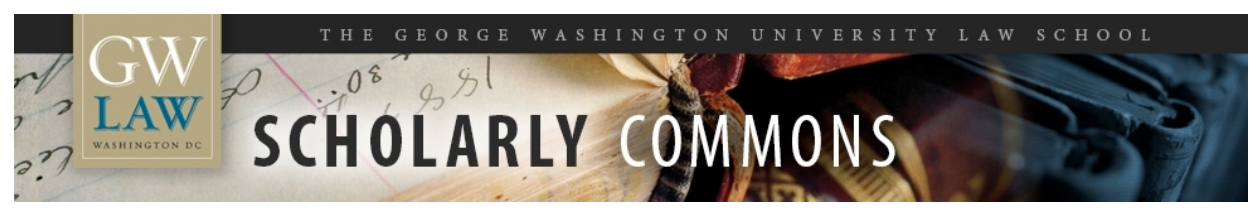

GW Law Faculty Publications \& Other Works

Faculty Scholarship

2005

\title{
Lessons for Competition Policy from the Vitamins Cartel
}

William E. Kovacic

George Washington University Law School, wkovacic@law.gwu.edu

Follow this and additional works at: https://scholarship.law.gwu.edu/faculty_publications

Part of the Law Commons

\section{Recommended Citation}

William E. Kovacic, Lessons for Competition Policy from the Vitamins Cartel, 74 St. John's L. Rev. 361 (2000).

This Article is brought to you for free and open access by the Faculty Scholarship at Scholarly Commons. It has been accepted for inclusion in GW Law Faculty Publications \& Other Works by an authorized administrator of Scholarly Commons. For more information, please contact spagel@law.gwu.edu. 


\title{
Lessons for Competition Policy from the Vitamins Cartel
}

\author{
William Kovacic \\ Robert C. Marshall \\ George Washington University \\ Penn State University \\ Leslie M. Marx \\ Matthew E. Raiff* \\ Duke University \\ Bates White, LLC
}

September 2005

\begin{abstract}
Mergers have the potential for negative social welfare consequences from increased likelihood or effectiveness of future collusion. This raises the question of whether there are meaningful thresholds for the postmerger industry that should trigger significant scrutiny by the Department of Justice or Federal Trade Commission. This paper provides empirical analysis relevant to this question. The data does not come from an industry in which there were mergers, but instead from an industry in which explicit collusion was admittedly rampant in the 1990's, the Vitamins Industry. Different vitamin products are produced by different numbers of firms, and for different vitamin products, different numbers of firms were involved in the conspiracy. In analyzing post-plea pricing, we find that duopolies continue as if the explicit conspiracy never stopped, while products with three or four cartel firms return to pre-conspiracy pricing, or lower, quite quickly. Although it is difficult to extrapolate to other industries, the evidence suggests that, by itself, a proposed reduction in the number of firms manufacturing a given product from four to three via a merger is not problematic in terms of conduct following explicit collusion. The danger of a three firm industry is that it is close to duopoly, and the collusive benefits of duopoly appear to be sustainable well past intervention by enforcement authorities.
\end{abstract}

*We thank Brian McClelland and Scott Lobel for valuable research assistance, and we thank seminar participants at the Federal Communications Commission for helpful comments. This paper was completed while Marx was visiting the FCC. The opinions expressed in this paper are those of the authors and do not necessarily represent the views of the FCC or any other member of its staff. 


\section{Introduction}

A major social welfare concern regarding a potential merger is the impact of increased concentration on the future suppression of interfirm rivalry within the industry. The Horizontal Merger Guidelines of the Department of Justice (DOJ) and Federal Trade Commission (FTC) ${ }^{1}$ implicitly mandate an analysis of the increased chances of future coordination as well as the increased payoffs from any incremental coordination among firms in an industry:

Arguments regarding the change in coordinated effects from a merger have historically consisted of four components. First, if there are a substantial number of firms remaining after the merger, then adverse effects are viewed as relatively unlikely. Second, if the Herfindahl index rises by more than 100 points from the merger, then the merger is viewed as being worthy of further investigation for adverse social effects through coordinated effects. Third, the Guidelines make special note of "Maverick" firms - if a Maverick is part of a merger, then the merger is viewed as having potentially adverse social effects, but if a Maverick exists in the industry and is not involved with the merger, then the merger is viewed with less concern. Fourth, arguments are made, rooted in the Folk Theorem and economics literature on tacit collusion, about the change from pre-merger to post-merger in the possibility of interfirm monitoring and punishment for deviant behavior.

According to the Horizontal Merger Guidelines (at Section 2.1):

A merger may diminish competition by enabling the firms selling in the relevant market more likely, more successfully, or more completely to engage in coordinated interaction that harms consumers. Coordinated interaction is comprised of actions by a group of firms that are profitable for each of them only as a result of the accommodating reactions of the others. This behavior includes tacit or express collusion, and may or may not be lawful in and of itself.

In light of this, a natural research program involves empirical studies of industries in which mergers were approved. Do prices in these industries reflect increased interfirm coordination? And if there are periods of increased coordination, is this increased coordination short-lived? Specifically, are periods of increased coordination

\footnotetext{
${ }^{1}$ Available at http://www.usdoj.gov/atr/public/guidelines/horiz_book/hmg1.html.
} 
followed by a return to pre-merger prices, or do prices remain elevated above premerger levels? There are few studies of this nature due to data availability, ${ }^{2}$ as well as potential hesitations about making cross-industry comparisons.

Such studies would inform social policy and provide significant guidance for enforcement agencies regarding the allocation of their scarce resources. Specifically, if the answers to the questions suggested above vary according to the number of firms in the post-merger industry, then one might find a threshold value for the number of post-merger firms such that a merger than reduces the number of post-merger firms below the threshold can be expected to have significant negative welfare implications from subsequent coordinated effects.

The early literature in industrial organization discusses how, in industries with small numbers of firms, firms might be expected to recognize their mutual interdependence and that one might expect relatively more collusive outcomes in industries with relatively fewer firms (see Chamberlin, 1933; Bain, 1951; and Stigler, 1964). Later work provides experimental and theoretical support for the idea that the competitiveness of an industry with a small number of firm can be expected to be increasing in the number of firms. ${ }^{3}$ Selten's (1973) paper argues that "four are few, six are many," so that six firms are sufficiently many that collusive outcomes are unlikely. The empirical work of Kwoka (1979) leads him to conclude that "three-firm coordination problems are so severe as to make a large third firm more likely a rival." Thus, his results suggest that in many cases three firms are sufficiently many to prevent collusive outcomes. The empirical work of Bresnahan \& Reiss (1991) lead them to conclude that once there are three to five firms in an industry, a new entrant has little effect on the competitiveness of the industry, suggesting that three to five firms are sufficient to prevent collusive outcomes. Recent experimental work by Huck, Normann, and Oechssler (2004) suggests competitiveness is monotonic in the number of firms and that four or five firms is sufficient to prevent collusive outcomes.

Since the mid-1990s, the DOJ and the FTC ordinarily sued to block horizontal mergers that would have reduced the number of market participants to three or fewer

\footnotetext{
${ }^{2}$ Enforcement agencies should mandate, as a condition of merger approval, that certain information be made available to them post-merger on an ongoing basis, and they should devote staff resources to the analysis of this data.

${ }^{3}$ Dolbear, et al. (1968) provide experimental results, and Selten (1973) provides theoretical results. Also, Werden and Baumann (1986) provide theoretical results in which competitiveness is nonmonotonic in the number of firms. In their model, damages increase more slowly than the benefits of collusion as the number of firms increases.
} 
firms. As a rough generalization, over the past decade, antitrust lawyers confidently have been able to advise the parties to proposed mergers that, based on an examination of the agencies' decisions to prosecute, the threshold at which the federal authorities would sue to block deals is four-to-three. ${ }^{4}$ As Table 1 below indicates, this litigation threshold has shifted significantly over the past half-century.

Table 1

DOJ/FTC Merger Policy: Litigation Threshold for Horizontal Mergers 1960-2005

\begin{tabular}{|c|c|}
\hline Decade & Threshold of Likely Litigation Challenge \\
\hline $1960 \mathrm{~s}$ & Merger reduces number of survivors to 12 or fewer firms \\
\hline $1970 \mathrm{~s}$ & Merger reduces number of survivors to 8 or fewer firms \\
\hline $1980 \mathrm{~s}$ & Merger reduces number of survivors to 5 or fewer firms \\
\hline $1990 \mathrm{~s}$ & Merger reduces number of survivors to 3 or fewer firms \\
\hline $2000 \mathrm{~s}$ & Merger reduces number of survivors to 3 or fewer firms \\
\hline
\end{tabular}

These adjustments have been the result of two interrelated developments: DOJ and FTC self-assessments driven by changes in the state of research and scholarly commentary, and judicial decisions that retreated from the strong presumptions of illegality adopted by courts in the 1960s and imposed more demanding burdens upon the federal agencies when seeking to block horizontal mergers. ${ }^{5}$

The existing economics literature suggests that if five similar-sized firms will remain post-merger, then the merger should not be viewed as problematic from a coordinated effects standpoint. The existing literature does not clearly address whether a merger that reduces the number of firms from five to four or from four to three should be viewed as problematic. Thus, empirical studies that can address these

\footnotetext{
${ }^{4}$ There have been exceptions to this general proposition. FTC's complaint in its unsuccessful challenge in 2004 to the acquisition by Arch Coal of Triton alleged that the number of firms in one relevant market following the merger would have fallen from five to four. Federal Trade Commission v. Arch Coal Co., 329 F. Supp. 2d 109 (D.D.C. 2004). It is also possible to identify some horizontal transactions (particularly in the aerospace and defense sectors) over the past decade for which the federal antitrust agencies took no action even though the number of surviving firms fell to less than three. Kovacic (2003, 444-47).

On the promulgation and revision of merger guidelines by the federal agencies since the 1960, see Greene (2005); Symposium (2003). On the influence of judicial decisions and the change in merger jurisprudence since 1960, see Gavil et al. (2002, 418-558); Leary (2002).

${ }^{5}$ On the promulgation and revision of merger guidelines by the federal agencies since the 1960, see Greene (2005); Symposium (2003). On the influence of judicial decisions and the change in merger jurisprudence since 1960, see Gavil et al. (2002, 418-558); Leary (2002).
} 
number could provide a useful guide for enforcement agencies' as to where to invest scarce resources in challenging mergers on the basis of coordinated effects.

In this paper, we analyze price data for thirty-one vitamin products for which we have observations that span three period of time: prior to a period of admitted explicit collusion, during a period of admitted explicit collusion, and after a period of admitted explicit collusion. The period of admitted explicit collusion spans much of the 1990's, when many of the manufacturers of vitamins admitted their guilt regarding participation in a worldwide price-fixing conspiracy. ${ }^{6}$

There are many different vitamins, and an even greater number of vitamin products. The number and identities of firms that can produce each vitamin product differ across the products, as did the number of cartel participants. Yet, there is not significant heterogeneity in the factor inputs used to produce different vitamin products, and demand fluctuations tend to affect vitamin products in similar ways. Thus, we are able to attribute much of the difference in pricing behavior to the number of firms producing the different vitamin products.

We analyze the price path for these vitamin products after the end of the pleaperiod. This allows us to examine whether, after a period of explicit collusion, firms can maintain prices at cartel levels, or whether there is erosion in prices relative to their explicitly collusive levels. We examine whether the price paths following the plea periods for the different vitamin products depend on the number of firms engaged in the previous explicit collusion, controlling of the magnitude of the fringe producers. This analysis allows us to obtain a partial understanding of how market concentration impacts the efficacy of tacit collusion.

Our primary finding is that duopolies continue as if the explicit conspiracy never stopped while products with three or four cartel firms return to pre-conspiracy pricing, or lower, quite quickly.

\section{Coordinated Effects Analysis}

Concern about postmerger coordinated effects has supplied the main conceptual basis for antitrust scrutiny of horizontal transactions since the Celler-Kefauver Amendment

\footnotetext{
${ }^{6}$ Explicit collusion may have existed prior to the beginning of the period of admitted guilt. In fact, recent work (Marshall, Marx, and Raiff, 2005) suggests that the collusion may have started in the mid-80's.
} 
to the Clayton Act's merger control provision in $1950 .{ }^{7}$ The views of scholars, enforcement agencies, and courts about the appropriate application of coordinated effects analysis have undergone considerable change over the past half-century. Through the 1960 s, merger doctrine and enforcement policy reflected acute apprehension about the oligopoly gap - the zone in which firms in moderately or highly concentrated industries could realize supranormal returns by accounting for their interdependence in ways that did not transgress the Sherman Act's prohibitions on express collusion and abusive single-firm behavior. ${ }^{8}$

In the 1950s and 1960s, many economists and lawyers endorsed measures to address the oligopoly gap directly by deconcentrating industries with oligopoly market structures. ${ }^{9}$ Although many observers regarded deconcentration was the preferred solution, merger policy had a key role to play in ensuring that horizontal combinations did not create new oligopolies or increase the effectiveness of tacit coordination in already concentrated industries. As suggested above, U.S. merger policy in the 1960s and early 1970s aggressively policed horizontal mergers, and Supreme Court decisions establishing powerful (and typically decisive) presumptions of illegality for transactions that resulted in post-acquisition market shares of less than ten percent. ${ }^{10}$

The reliance of merger doctrine and enforcement policy upon structural presumptions fell under heavy scholarly attack. Much of the criticism raised doubts about how effectively oligopolists could coordinate their behavior by tacit means - that is, without resorting to an overt or covert exchange of assurances. ${ }^{11}$ From at least the

\footnotetext{
${ }^{7}$ The 1950 amendments established the basic substantive framework of today's merger control regime. See Gellhorn et al. (2004, 418-21) (describing rationale for and history of the 1950 amendments to Section 7 of the Clayton Act).

${ }^{8}$ For a representative synthesis of this view, see Kaysen and Turner $(1959,110)$ (observing that "[t]he principal defect of present antitrust law is its inability to cope with market power created by jointly acting oligopolists). See also Kovacic \& Shapiro (2000, 51-52).

${ }^{9}$ See Kovacic $(1989,1136-39)$ (recounting proposals by economists and lawyers to deconcentrate oligopoly sectors). Congress declined to enact the deconcentration legislation, and efforts by the federal antitrust agencies to use the existing antitrust laws to restructure oligopolies - for example, through the prosecution of "shared monopoly" cases by the FTC - were entirely unsuccessful. See Kellogg Co., 99 F.T.C. 8, 269 (1982) (dismissing shared monopolization complaint against leading U.S. producers of breakfast cereal); Exxon Corp., 98 F.T.C. 453, 461 (1981) (dismissing shared monopolization complaint against leading refiners of petroleum products).

${ }^{10}$ See, e.g., United States v. Pabst Brewing Co., 384 U.S. 546 (1966) (prohibiting merger that yielded a post-acquisition market share of 4.49 percent).

${ }^{11}$ See Baker (1993) (describing evolution of economic thinking about oligopoly and the feasibility and frequency of effective coordination). An important stimulus for this line of inquiry was George Stigler's work (1964) on the difficulties that firms face in achieving effective coordination when they seek to orchestrate their behavior through express, rather than tacit, means.
} 
late 1970 s to the present, this perspective has influenced courts and enforcement agencies in two basic ways. First, it has dramatically shifted the structural threshold of concern in horizontal merger cases. Decisions of the courts have weakened the power of the structural presumption in coordinated effects cases except at the highest levels of concentration. ${ }^{12}$ Second, as reflected in judicial decisions such as Arch Coal in the United States and AirTours in the European Union, the enforcement agencies have been pressed in coordinated effects cases to explain more fully and convincingly how coordination among the surviving firms will take place in the post-merger period. ${ }^{13}$

In light of these developments, a major challenge for enforcement agencies in future coordinated effects cases is to improve the basis for predicting the competitive consequences of individual cases and, in litigated disputes, to provide a more confident basis for courts to infer that specific consolidations will have anticompetitive effects. One means to this end is for the enforcement community to take steps to strengthen the empirical foundations of merger analysis. In recent years the U.S. agencies have invested additional resources in "competition policy research and development" (Kovacic 2005). These investments have included ex post assessments of the competitive effects of completed mergers (Muris \& Pitofsky 2005, 827-28) and the review of past merger reviews to identify evidence that most strongly influenced the decision whether to challenge transactions (FTC 2004).

A promising additional frontier for empirically-oriented research relevant coordinated effects analysis is for competition agencies to study their experience with the enforcement of antitrust laws against cartels. ${ }^{14}$ Government competition authorities have accumulated considerable experience in anti-cartel enforcement programs, and the examination of individual enforcement episodes can yield valuable insights about industry conditions in which tacit coordination is most likely to be effective. The examination of the Vitamins Cartel in the sections that follow illuminate the possibilities of such a research program.

\footnotetext{
${ }^{12}$ See, e.g., FTC v. H.J. Heinz Co., 246 F.3d 708 (D.C. Cir. 2001) (condemning acquisition that reduced the number of firms in the relevant market from three to two); see also Baker (2004) (discussing application of structural presumption in Heinz case).

${ }^{13}$ See FTC v. Arch Coal Co., 329 F. Supp. 2d 109 (D.D.C. 2004); AirTours plc v. Commission, Case T-342/99, [2002]ECR II-2585.

${ }^{14}$ Some of these possibilities are suggested in Kolasky (2002).
} 


\section{Data from the Vitamins Industry}

\subsection{Overview}

Vitamins are produced and purchased for both human and animal consumption. Each vitamin has a specific set of beneficial effects. When considering the cost of producing animal feed or human food, the incremental cost of the vitamin additives typically is small. Due to the significant nutritional impact of vitamin supplements, the demand for vitamins is highly inelastic.

Although it is common to think of vitamins as a single entity - such as Vitamin A or Vitamin E-in fact, specific vitamin products are manufactured within each vitamin type. For example, in this section, we consider four different Vitamin A products: A Acetate 500 USP, A Palmitate 250 USP, A Palmitate 500 USP, and A Acetate 650 Feed.

Vitamins are largely produced through processes of chemical synthesis, although there have been recent advances in fermentation technologies for the production of some vitamins. The industry is highly concentrated, and the large capital investments, and especially the production experience, required for the manufacture of vitamins are a barrier to entry. Although the major producers have similar production technologies, the chemical synthesis processes involve substantial "learning by doing." Each producer becomes better, through time, at debottlenecking the chemical synthesis process at any given plant. A given vitamin product made by one firm is chemically identical to the same product made by another firm.

In the late 1990s, the DOJ obtained guilty pleas from several major vitamin manufacturers for participating in an international price fixing cartel that extended back to at least January 1990. In addition, the European Community and Canada found that several of the vitamin producers had violated antitrust laws within their jurisdictions. In this report, we refer to the interval of the DOJ plea dates as the "plea period."

Detailed descriptions of the vitamins conspiracy can be found in the European Commission's (2003) decision. In general, the cartel fixed the market shares of the colluding firms, referring to these shares as "budget targets," and monitored the output of the cartel members. The cartel used interfirm output transactions as a mechanism for rectifying any internal issues that arose, whether these were adherence to budgeted market share allocations or other matters regarding the enhancement of 
cartel profits. For example, "Any company that sold more than its allotted share was required in the following year to purchase the excess from another conspirator that had not reached its volume allocation target."

The cartels in the different vitamin products operated over approximately the same period of time in the 1990s, and possibly prior to 1990. The different vitamins have similar factor inputs and demand for the different vitamins in subject to similar shocks, although on the demand side, there may be some differences between vitamins intended for human use and those intended for use in animals. Because of this, we analyze human and feed vitamins separately. Among human vitamins and among feed grade vitamins, similarities in the environments in which the cartels operated, including the time periods and the supply and demand factors, allow us to make comparisons across vitamins.

\subsection{Data}

Price data on a set of vitamin products is available from the Expert Report of B. Douglas Bernheim, M.D.L. No. 1285, In Re: Vitamins Antitrust Litigation, Misc. No. 99-0197 (TFH), May 24, 2002. Section 12 of Bernheim (2002) provides data for 37 vitamin products, including the monthly weighted average unit price in dollars per kilogram from 1980 to 2002 (shorter time period for some vitamin products), the dates of the plea-period, the identities of the cartel firms, and the identities or locations (e.g., Eastern Europe) of non-cartel firms. In addition, Section 10 of Bernheim (2002) provides data for 2 additional vitamin products, Ascorbic Acid 100\% USP and E 50\% Adsorbate Feed Grade. For these two vitamin products, prices are broken out by producer, so we used the worldwide production shares for Vitamins $\mathrm{C}$ and E, given in Figures 8-7 and 8-1 of Bernheim (2002), to construct a weighted average price. ${ }^{15}$

As an example of the data that is available for each vitamin product in the Bernheim (2002) report, Figure 1 shows the data available for Vitamin A Acetate 650 Feed Grade. The information includes a weighted average price for the vitamin product, the plea-era sales value, and a list of the manufacturers, both cartel and non-cartel.

\footnotetext{
${ }^{15}$ Weights are given by year and are not available after 1998, so for years after 1998, the weights are assumed to be the same as in 1998. Figure 8-7 does not explicitly state BASF's Vitamin C production share four years. Based on the figure, we judge those shares to be $1980: 2 \% ; 1981: 2 \%$; 1989: 4\%; and 1996: $4 \%$.
} 


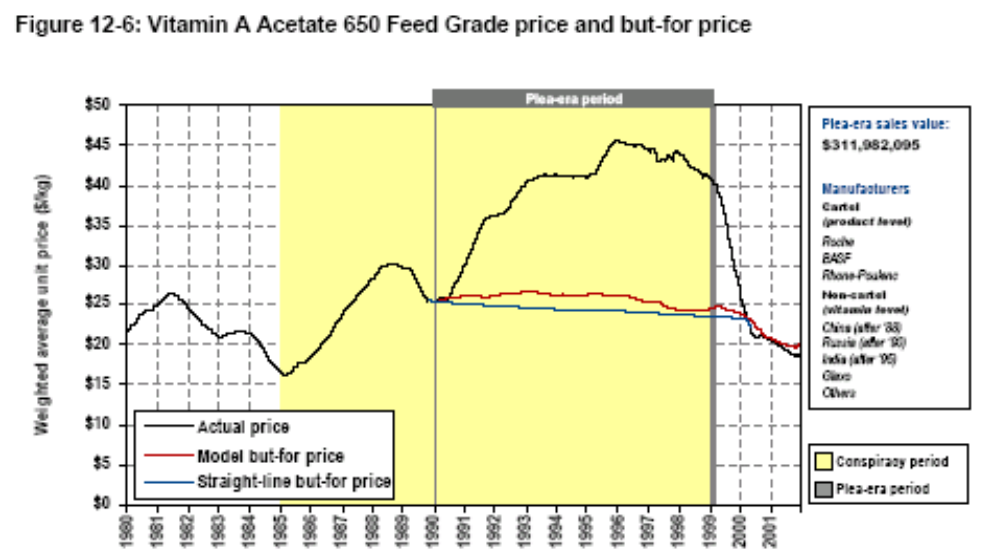

Source: 7-month centered moving average for U.S. "tel quel" feed price from Roche ROVIS data

Figure 1: Example of price data available from Bernheim (2002).

According to Bernheim (2002), the price data are derived from the Roche ROVIS database (except Choline Chloride (B4), which we do not include in our data), and the vitamin products in Section 12 are those that satisfy two requirements: the data must be consistently reported throughout the 1980 to 2001 time period (with a few exceptions) and the product must account for at least 1.5 percent of Roche's U.S. sales within the relevant vitamin family between 1980 and 2001 and account for at least $\$ 10$ million in Roche sales volume over the same period.

To improve comparability across vitamin products, we focus on vitamin products that are produced by Roche. This eliminates six vitamin products, including two Choline Chloride products, three Niacin products, and Vitamin B12 Crystals. In addition, we drop the two Biotin products because they are outliers in a number of ways: they are the only two vitamin products with five firms in the cartel (the other Roche vitamins have four or fewer in the cartel); they are small in terms of the dollar amount of sales during the plea period (they have less than $\$ 9$ million in plea sales, whereas the average plea sales of the other Roche vitamins is over $\$ 97$ million); and the identities of the cartel firms, although Roche is one, are not consistent with those of the other Roche vitamin products (the Biotin products are the only Roche products that are also produced by Tanabe and Lonza). That leaves us with the thirty-one vitamin products shown in Table 2. 
Table 2

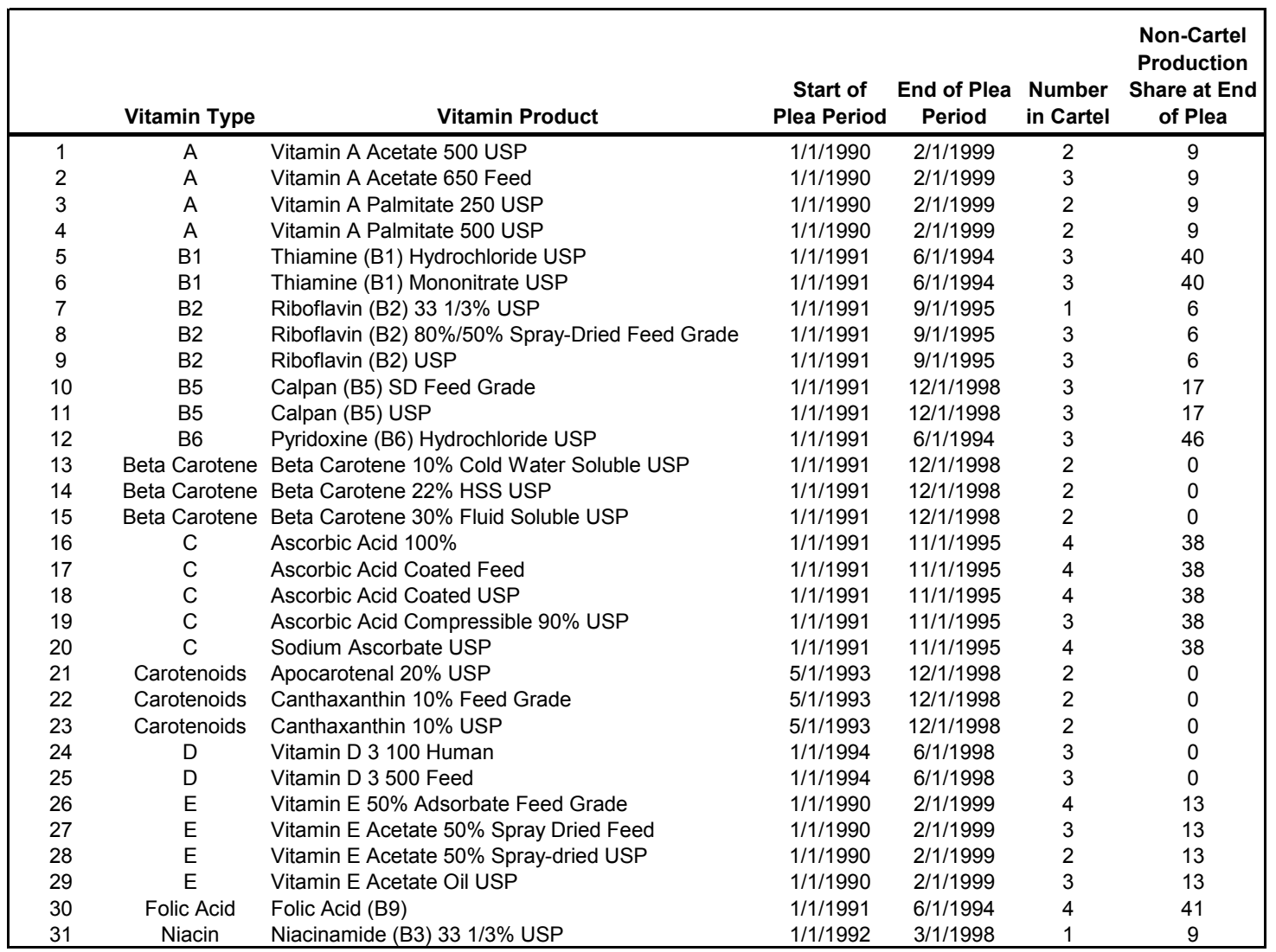

To define the plea period for each vitamin product, we use the U.S. plea period for that product's vitamin type if there is one, and otherwise we use the EC or Canadian plea period as given in Bernheim (2002, Table 6). For vitamin products with both EC and Canadian plea periods, but no U.S. plea period, we use the EC plea period.

Note that Table 2 shows two vitamin products that have only one firm in the "cartel." For these vitamin products, Roche is the only manufacturer charged with illegal activity. The data for these two vitamin products give us some idea of how a monopolist manufacturer would behave. One can view the price increase during the plea period for those products as related to the increase in the prices of substitute products rather than due to conspiratorial behavior among the manufacturers of those products.

Although the plea periods vary for the different vitamin products, data are available for all the vitamin products in our sample for 48 months prior to the beginning of their plea periods and for 28 months after the end of their plea periods. Thus, for each vitamin product, for a given number of months before the beginning of the plea 
period or after the end of the plea period, we can calculate the percentage change in price relative to the maximum price achieved during the plea period.

Figures 2 and 3 show for feed and human vitamin products, respectively, on the horizontal axis the number of months prior to the start of the plea period (negative numbers) and the number of months after the end of the plea period (positive numbers), and on the vertical axis the percentage change in price relative to the maximum price achieved during the plea period. Note that we are not claiming that the behavior in the Vitamins Industry prior to the plea period was non-collusive; to the contrary, the analysis of the vitamin manufacturers' public price announcements by Marshall, Marx, and Raiff (2005) suggests that the period of collusion extended back to January of 1985 . We address this more formally in Section 4.3.

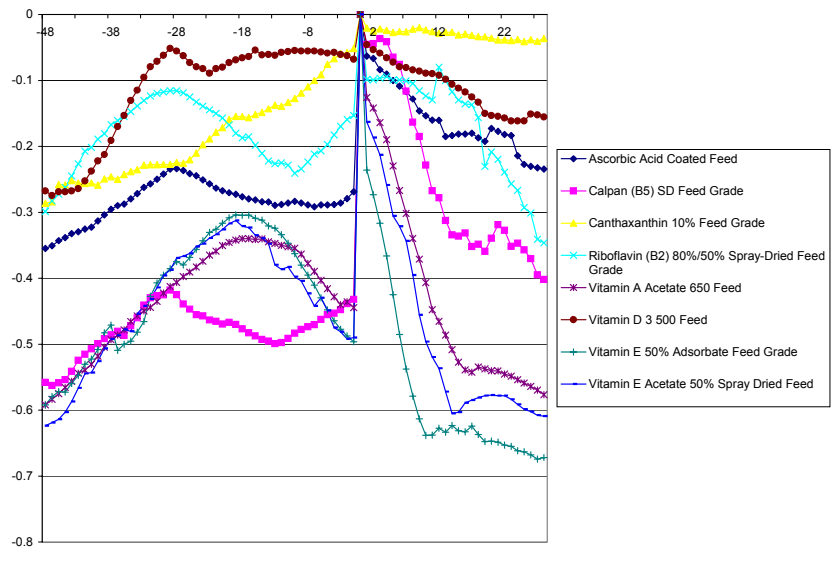

Figure 2: Percentage change in price relative to the plea-period maximum for feed grade vitamin products. Negative dates indicate months prior to the beginning of the plea period. Positive dates indicate months after the end of the plea period. 


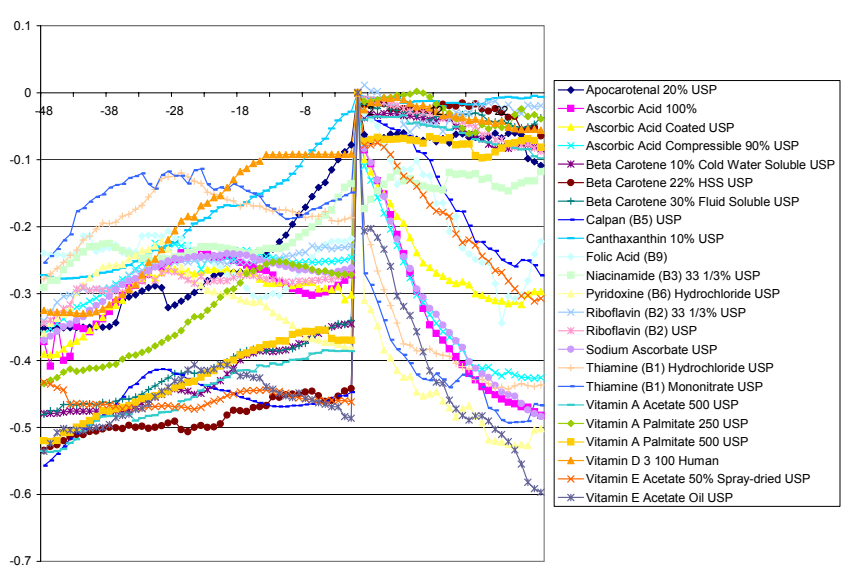

Figure 3: Percentage change relative to the plea-period maximum for human vitamin products. Negative dates indicate months prior to the beginning of the plea period. Positive dates indicate months after the end of the plea period.

The data are not useful for examining the propensity of firms to form an explicit cartel since we only have the data because there were explicit cartels in all products. However, the data are potentially good for examining the propensity of firms who were explicitly colluding to continue in something close to that manner after the plea period. This has implications for merger policy. If prices remain high after the plea period, there is a reasonable chance that the firms may have discovered the advantages of tacit collusion without explicit collusion. And, if there are differences in post-plea prices based on the number of firms in the cartel, this may indicate differences in the ability of firms to sustain tacit collusion depending on the number of firms involved.

In what follows, we contrast the data for vitamin products in which only one producer was charged with illegal activity with vitamin products in which there were two-firm cartels, three-firm cartels, and four-firm cartels and ask whether there are differences in post-plea pricing that would suggest a merger that reduces the number of producers to a particular number of firms should be a concern as far as the competitiveness of the industry is concerned. 


\section{Analysis}

\subsection{Graphical Analysis}

We now consider the percentage change in price relative to the plea-period maximum for the different vitamin products broken out by the number of firms in the cartel.
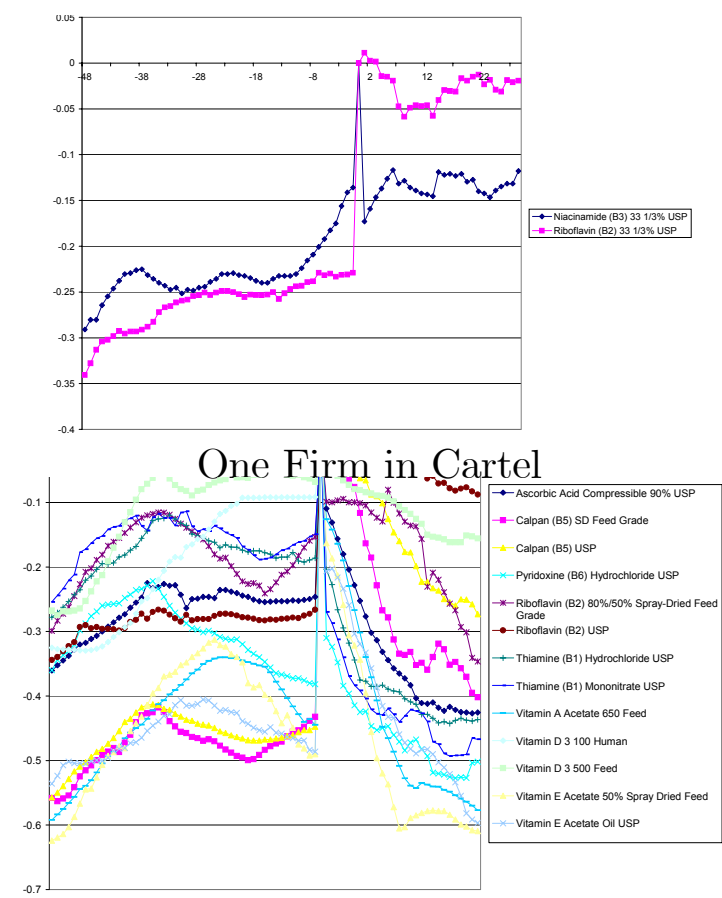

Three Firms in Cartel

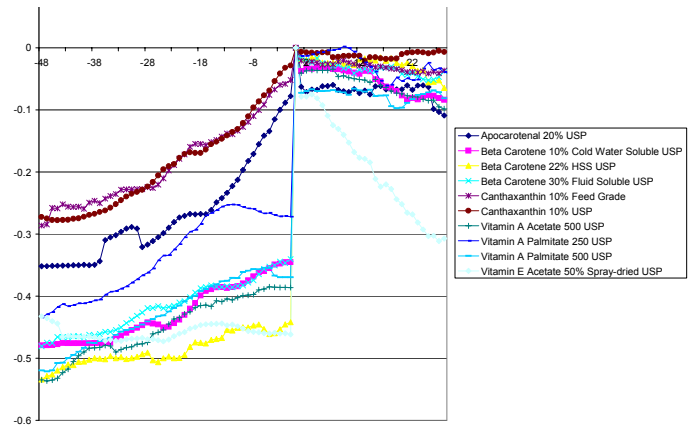

Two Firms in Cartel



Four Firms in Cartel

Figure 4: Percentage change in price relative to plea-period maximum by product.

We see that for vitamin products with only one firm in the cartel, especially Riboflavin, prices remained high after the plea period relative to their pre-plea levels. For all but one of the vitamins products with a two-firm cartel, prices remain close to their plea-period maxima. The price of Vitamin E Acetate 50\% SD USP falls after the end of the plea period, but after more than two years, remains well above its pre-plea levels. For the cartels involving three firms, the evidence is somewhat mixed. ${ }^{16}$ Prices for some products remain above their pre-plea levels, but others drop sharply after the end of the plea period. For four-firm cartels, in all cases, the price

\footnotetext{
${ }^{16}$ Bernheim (2002) states, "In the case of Riboflavin (B2), the evidence suggests that Roche attempted to re-cartelize the market with Rhone-Poulenc after the end of the conspiracy period. This may have prolonged the effects of the original conspiracy and delayed the onset of non-conspiratorial price dynamics.
} 
eventually ends up below pre-plea nominal levels (for Ascorbic Acid Coated Feed, the price does not drop below pre-plea levels until mid 1999, 41 months after the end of the plea period). The rate of descent varies for these vitamin products, with the prices in coated Vitamin $\mathrm{C}$ products descending less rapidly than for many of the other vitamin products.

We now combine the graphs described above, averaging across vitamin products, to obtain the average price changes relative to the plea-period maximum for vitamin products with different numbers of cartel members.

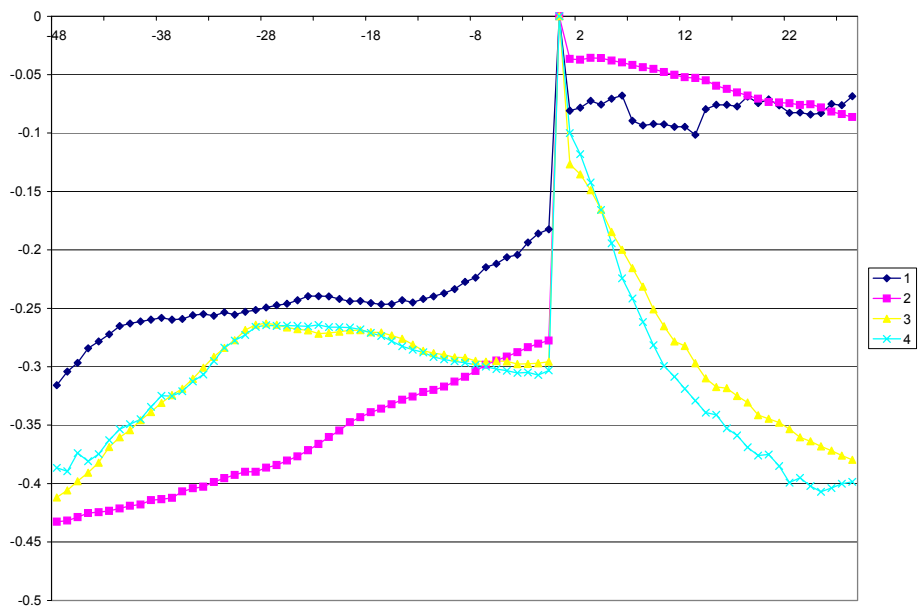

Figure 5: Average percentage change in price relative to the plea-period maxima by number in cartel. Negative dates indicate months prior to the beginning of the plea period. Positive dates indicate months after the end of the plea period.

Figure 5 shows a dramatic difference between the prices of one and two-firm cartels versus larger cartels in the post-plea period. When there is only one primary producer or there is a two-firm cartel, firms are able to maintain prices significantly above preplea levels. This is despite the fact that for most vitamin products in our sample, there are competing non-cartel producers. The prices for three and four-firm cartels remain elevated above their pre-plea levels for approximately one year after the end of the plea period.

Relative to pre-plea levels, for two, three, and four-firm cartels, the plea-period maximum price is approximately $30 \%$ higher; however, for one-firm cartels, the pleaperiod maximum price is only $18 \%$ higher than the pre-plea price. This may be 
because for one-firm cartels, the pre-plea price is already close to the monopoly level, and any increase in price may be more a result of the increase in the price of substitute products rather than conspiratorial behavior in that vitamin product.

To provide three additional ways to view the data, we also consider the percentage price change relative to the price in January of 1985, relative to one month prior to the beginning of the plea period, and relative to the final month of the plea period. Note that we only have data for all vitamin products for 28 months after the end of the plea period, but beyond 28 months after the end of the plea period, some vitamin products drop out of our data.

We begin with price changes relative to the month prior to the beginning of the plea period.

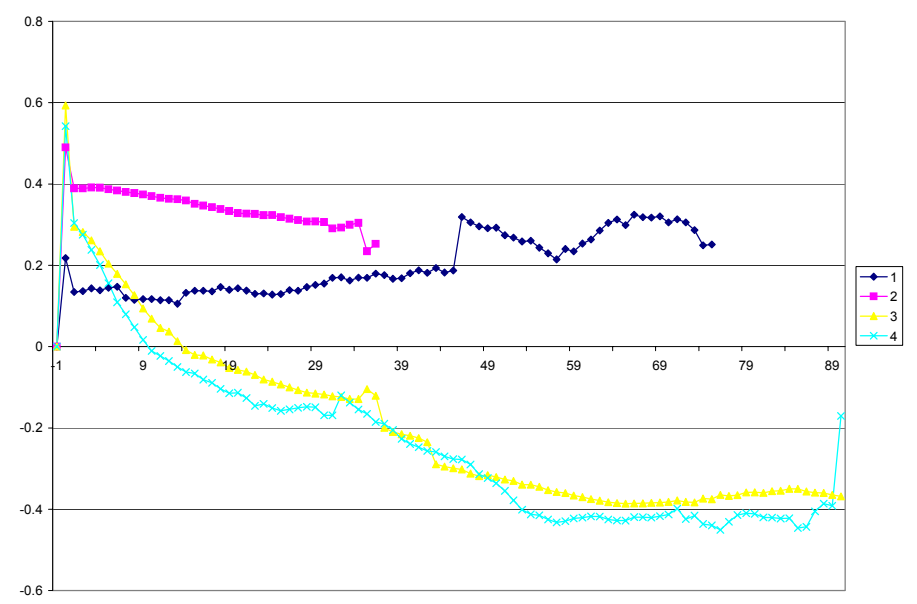

Figure 6: Average percentage change in price relative to one month prior to the beginning of the plea period by number in the cartel. The price change shown at date zero is the for maximum price during the plea period. Positive dates indicate months after the end of the plea period.

Figure 6 shows that price for two, three, and four-firm cartels increase between $49 \%$ and $59 \%$ during the plea period relative to one month prior to the plea period. For one-firm cartel, the price only increases about $22 \%$. As mentioned above, this may be because for vitamin products with only one major producer, the pre-plea prices were already close to their monopoly levels. For one and two-firm cartels, prices remain well above their pre-plea levels. For one-firm cartels, prices remain 
close to their plea-period maxima long after the end of the plea period and show no signs of decay. For two-firm cartels there is slight decay, but prices remain more than $20 \%$ above their pre-plea levels over three years after the end of the plea period. For three and four-firm cartels, prices fall to their pre-plea levels within ten months for four-firm cartels and within fourteen months for three-firm cartels. It is interesting that prices for three and four-firm cartels fall to about $40 \%$ below their pre-plea levels in the five months after the end of the plea period. This may be due to competition from new entrants whose entry was induced by the high prices during the plea period.

Figure 7 provides similar information, but uses the price on January 1, 1985 as the reference point. ${ }^{17}$ We include this graph because the analysis of Marshall, Marx, and Raiff (2005) suggests that the collusive period in the Vitamins Industry extended back to 1985. In fact, the general upward trend in prices show in Figure 7 between month -60 and month zero, and the fact that prices fall below their 1985 levels after the end of the plea period for three and four-firm cartels, provide additional support for this.

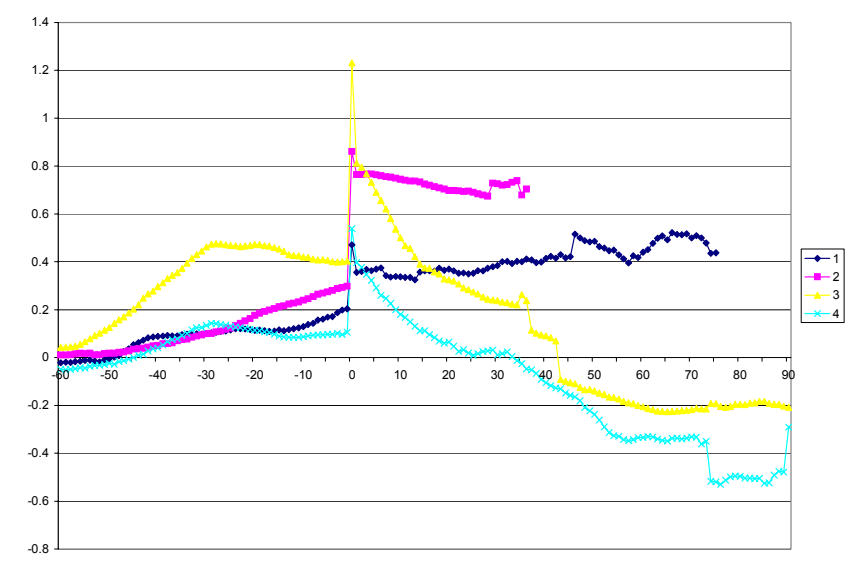

Figure 7: Average percentage change in price relative to the price in January of 1985 by number in the cartel. The price change shown at date zero is the for maximum price during the plea period. Negative dates in dicate months prior to the beginning of the plea period, and positive dates indicate months after the end of the plea period. Month -60 corresponds to January 1985 for most vitamin products.

\footnotetext{
${ }^{17}$ The sample used for Figure 7 does not include Ascorbic Acid 100\% or Vitamin E 50\% Adsorbate Feed Grade because the data for these two vitamins does not extend back to January of 1985 .
} 
Figure 8 provides a slightly different perspective from Figures 6 and 7 . Instead of using a date prior to the plea period as a benchmark, it uses the last month of the plea period as the benchmark. Thus, Figure 8 provides information about the sustainability of cartel prices after the end of explicit collusion.

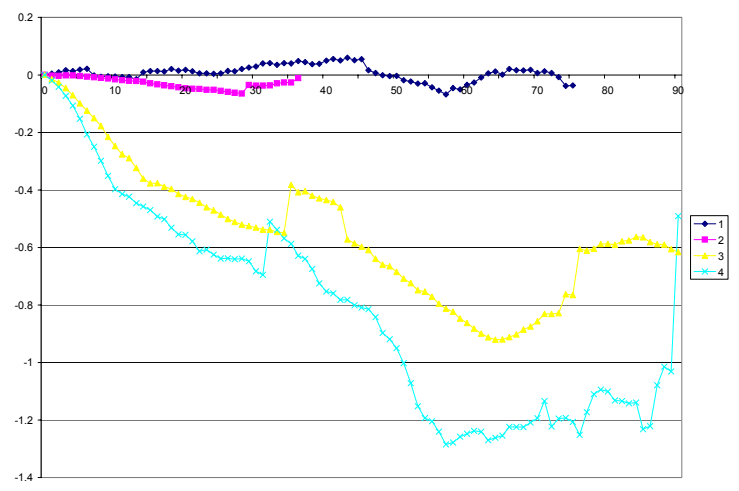

Figure 8: Average percentage change in price relative to the last month of the plea period by number in the cartel. Date zero is the last month of the plea period, and positive dates indicate months after the end of the plea period.

Figure 8 shows that prices for one and two-firm cartels remain steady from the end of the plea period out as far as our data allows. In contrast, the prices for three and four-firm cartels decrease rapidly after the end of the plea period, with the prices of vitamin products with four-firm cartels falling somewhat faster than those of vitamin products with three-firm cartels. Note that some of the jumps in the data shown in Figure 8 for three and four-firm cartels occur because certain vitamin products drop out of the data at different numbers of months after the end of the plea period.

\subsection{Review of a Simple Model}

In this section we remind readers of a simple model based on Cournot competition and linear demand. This model provides some insights that can be used to understand what appear to be differences in the viability of tacit collusion based on the number of firms in the industry.

Assume there are $n$ firms producing a homogenous product with common constant marginal cost $c$. Assume industry inverse demand is $P=a-b Q$, where $a>c \geq 0$ 
and $b>0$. Assuming either Cournot competition or fully collusive behavior, we can calculate the profits for the firms in our model.

Table 3

\begin{tabular}{|c|c|c|c|c|c|}
\hline & Cournot & All-inclusive & All-inclusive & \multicolumn{2}{|c|}{ Profit if other $n-1$ collude } \\
\cline { 5 - 6 } & profit & cartel profit & cartel profit/firm & In cartel & Outside cartel \\
\hline$n$ & $\frac{(a-c)^{2}}{b(n+1)^{2}}$ & $\frac{(a-c)^{2}}{4 b}$ & $\frac{(a-c)^{2}}{4 b n}$ & $\frac{(a-c)^{2}}{(n-1) 9 b}$ & $\frac{(a-c)^{2}}{9 b}$ \\
\hline$n=1$ & $\frac{(a-c)^{2}}{4 b}$ & $\frac{(a-c)^{2}}{4 b}$ & $\frac{(a-c)^{2}}{4 b}$ & - & - \\
\hline$n=2$ & $\frac{(a-c)^{2}}{9 b}$ & $\frac{(a-c)^{2}}{4 b}$ & $\frac{(a-c)^{2}}{8 b}$ & - & - \\
\hline$n=3$ & $\frac{(a-c)^{2}}{16 b}$ & $\frac{(a-c)^{2}}{4 b}$ & $\frac{(a-c)^{2}}{12 b}$ & $\frac{(a-c)^{2}}{18 b}$ & $\frac{(a-c)^{2}}{9 b}$ \\
\hline$n=4$ & $\frac{(a-c)^{2}}{25 b}$ & $\frac{(a-c)^{2}}{4 b}$ & $\frac{(a-c)^{2}}{16 b}$ & $\frac{(a-c)^{2}}{27 b}$ & $\frac{(a-c)^{2}}{9 b}$ \\
\hline
\end{tabular}

Note that when there are two firms in an industry, each firm can increase its profit by colluding. If a firm chooses not to collude, the industry necessarily reverts to noncooperative play with two firms. However, when there are three firms in an industry, if two firms agree to collude, then the third firm strictly prefers to remain outside the cartel (and play non-cooperatively against the two-firm cartel) rather than join the two firms to form a three-firm cartel. This is apparent from Table 3, which shows that the profit from creating a three-firm cartel is $\frac{(a-c)^{2}}{12 b}$, but the profit from remaining outside while a two-firm cartel operates is $\frac{(a-c)^{2}}{9 b}$.

In order to get a sense for the order of magnitudes of these differences, Table 4 calculates the percentage change in a firm's profit from joining an all-inclusive cartel versus non-cooperative play, and the percentage change in a firm's profit from remaining outside the cartel when the other $n-1$ collude versus joining and creating an all-inclusive cartel.

Table 4

\begin{tabular}{|c|c|c|}
\hline & $\begin{array}{c}\% \Delta \text { in profit from joining } \\
\text { an all-inclusive cartel } \\
\text { versus non-cooperative play }\end{array}$ & $\begin{array}{c}\% \Delta \text { in profit from remaining } \\
\text { outside versus joining } \\
\text { when other } n-1 \text { collude }\end{array}$ \\
\hline$n$ & $\frac{(n+1)^{2}-4 n}{4 n}$ & $\frac{4 n-9}{9}$ \\
\hline$n=2$ & $\frac{1}{8}=12.5 \%$ & - \\
\hline$n=3$ & $\frac{1}{3}=33.3 \%$ & $\frac{1}{3}=33.3 \%$ \\
\hline$n=4$ & $\frac{9}{16}=56.3 \%$ & $\frac{7}{9}=77.8 \%$ \\
\hline
\end{tabular}


Table 4 shows that when there are three firms in an industry, the benefit to staying outside the cartel when the other two firms collude is the same magnitude as the benefit of all-inclusive collusion versus non-cooperative play. When there are four firms in the industry, there is an even larger benefit to staying outside the cartel when the other three firms collude.

More formally, this analysis shows that in our model an all-inclusive cartel is not in the core of the coalition formation game when there are three or more firms. ${ }^{18}$ When there are three or more firms, given any division of the cartel profits, there will be some firm that can profitably deviate by leaving the cartel. All-inclusive collusion is in the core when there are only two firms.

This model emphasizes that having more than two firms in an industry can be extremely disruptive to firms' attempts to collude. Furthermore, even if there is some collusion when there are more than two firms, the deadweight loss associated with collusion is greatly reduced if there is a large non-cartel presence in the market.

\subsection{Regression Analysis}

Although the price plots in Figures 4-8 suggest that there may be differences in postplea pricing based on the number of firms in the cartel, in this section we control for other factors that may explain the differences, such as the size of the non-cartel fringe and the end-use of the vitamin product. We present results for OLS regressions using as the dependent variable the percentage change in price over different periods of time. In regressions 1-4, we use the percentage change in price 12 and 24 months after the end of the plea period relative to the price one month prior to the beginning of the plea period. In regressions 5-8, we use the percentage change in price 12 and 24 months after the end of the plea period relative to the price in January of 1985. In regressions 9-12, we use the percentage change in price 12 and 24 months after the end of the plea period relative to the price during the last month of the plea period. Thus, regressions 1-4 can be related to Figure 6, regressions 5-8 can be related to Figure 7, and regressions 9-12 can be related to Figure 8.

As independent variables, we use a dummy that is one if the vitamin product is a feed vitamin, a dummy that is one if the non-cartel production share (at the vitamin level) in the last year of the plea is greater than or equal to $5 \%$ and less than

\footnotetext{
${ }^{18}$ This assumes that when one firm exits an $n$-firm cartel, the remaining $n-1$ firms continue to collude.
} 
$10 \%$, and a dummy that is one if the non-cartel production share (at the vitamin level) in the last year of the plea is greater than or equal to $10 \%{ }^{19}$ The dummies for the non-cartel production share provide some measure of the outside competition faced by the cartel and potentially also the ease of entry for that vitamin. Finally, we include dummies for whether the cartel for the vitamin product was a two-firm, three-firm, or four-firm cartel, with the one-firm cartel being the omitted category. For each dependent variable we run two regressions, one with dummies for two, three and four-firm cartels and one that drops the dummy for the two-firm cartel. We do this because there are only two products for which there is a monopoly producer.

Table 5 below gives descriptive statistics for the dependent and independent variables used in our regressions.

Table 5: Descriptive Statistics

\begin{tabular}{|c|c|c|c|c|c|c|c|c|c|}
\hline & Mean & Median & $\begin{array}{l}\text { Standard } \\
\text { Deviation }\end{array}$ & Kurtosis & Skewness & Range & Minimum & Maximum & Count \\
\hline $\begin{array}{c}\% \text { change from } \\
-1 \text { at }+12\end{array}$ & 0.133 & 0.067 & 0.277 & -0.589 & 0.508 & 1.076 & -0.317 & 0.758 & 31 \\
\hline $\begin{array}{c}\% \text { change from } \\
-1 \text { at }+24\end{array}$ & 0.047 & 0.015 & 0.289 & -0.599 & 0.492 & 1.132 & -0.403 & 0.729 & 31 \\
\hline $\begin{array}{l}\% \text { change from } \\
1 / 1985 \text { at }+12\end{array}$ & 0.502 & 0.499 & 0.365 & -0.982 & 0.042 & 1.225 & -0.087 & 1.138 & 29 \\
\hline $\begin{array}{l}\% \text { change from } \\
1 / 1985 \text { at }+24\end{array}$ & 0.394 & 0.441 & 0.379 & -1.055 & -0.054 & 1.345 & -0.243 & 1.102 & 29 \\
\hline $\begin{array}{c}\% \text { change from } \\
\text { last in plea at } \\
+12\end{array}$ & -0.140 & -0.097 & 0.156 & -0.141 & -0.887 & 0.566 & -0.532 & 0.035 & 31 \\
\hline $\begin{array}{c}\text { \% change from } \\
\text { last in plea at } \\
+24\end{array}$ & -0.203 & -0.193 & 0.184 & -1.128 & -0.405 & 0.614 & -0.574 & 0.040 & 31 \\
\hline Feed & 0.258 & 0 & 0.445 & -0.697 & 1.163 & 1 & 0 & 1 & 31 \\
\hline $\begin{array}{c}\text { non-cartel } \\
\text { share }[5-10)\end{array}$ & 0.258 & 0 & 0.445 & -0.697 & 1.163 & 1 & 0 & 1 & 31 \\
\hline $\begin{array}{c}\text { non-cartel } \\
\text { share }>=10\end{array}$ & 0.484 & 0 & 0.508 & -2.138 & 0.068 & 1 & 0 & 1 & 31 \\
\hline 2-firm cartel & 0.323 & 0 & 0.475 & -1.462 & 0.798 & 1 & 0 & 1 & 31 \\
\hline 3-firm cartel & 0.419 & 0 & 0.502 & -2.017 & 0.344 & 1 & 0 & 1 & 31 \\
\hline 4-firm cartel & 0.194 & 0 & 0.402 & 0.702 & 1.631 & 1 & 0 & 1 & 31 \\
\hline
\end{tabular}

In regressions 1-8, we focus on price changes relative to dates prior to the beginning of the plea period. The dependent variables used in these regressions provide measures of the lasting impact of explicit collusion on prices.

\footnotetext{
${ }^{19}$ Non-cartel production shares are available in Bernheim (2002), but only on an annual basis at the vitamin level (not the vitamin product level).
} 
Table 6: Regressions 1-8

\begin{tabular}{|c|c|c|c|c|c|c|c|c|}
\hline Regression Number & 1 & 2 & 3 & 4 & 5 & 6 & 7 & 8 \\
\hline \multirow{2}{*}{\begin{tabular}{|l} 
Dependent Variable \\
constant
\end{tabular}} & \multicolumn{2}{|c|}{$\begin{array}{c}\% \text { change in price at } \\
+12 \text { relative to first } \\
\text { month before plea }\end{array}$} & \multicolumn{2}{|c|}{$\begin{array}{l}\% \text { change in price at } \\
+24 \text { relative to first } \\
\text { month before plea }\end{array}$} & \multicolumn{2}{|c|}{$\begin{array}{r}\% \text { change in price at } \\
+12 \text { relative to } 1 / 1985 \\
\end{array}$} & \multicolumn{2}{|c|}{$\begin{array}{r}\% \text { change in price at } \\
+24 \text { relative to } 1 / 1985 \\
\end{array}$} \\
\hline & -0.0409 & 0.3023 & 0.0261 & 0.2918 & 0.2859 & 0.7121 & 0.3748 & 0.7100 \\
\hline & 0.1396 & 0.1103 & 0.1440 & 0.1031 & 0.1319 & 0.1045 & 0.1430 & 0.0966 \\
\hline \multirow{2}{*}{ feed } & -0.0741 & -0.0630 & -0.0787 & -0.0701 & 0.1408 & 0.1564 & 0.0934 & 0.1057 \\
\hline & 0.1001 & 0.0976 & 0.1010 & 0.0975 & 0.1683 & 0.1598 & 0.1665 & 0.1578 \\
\hline \multirow{2}{*}{ non-cartel share $[5,10)$} & 0.1552 & 0.0578 & 0.1017 & 0.0263 & 0.0485 & -0.0724 & -0.0247 & -0.1198 \\
\hline & 0.0986 & 0.1166 & 0.0978 & 0.1100 & 0.1113 & 0.1333 & 0.1196 & 0.1271 \\
\hline \multirow[t]{2}{*}{ non-cartel share $>=10$} & 0.0455 & 0.0086 & -0.0444 & -0.0729 & -0.2500 & -0.2953 & -0.3416 & -0.3772 \\
\hline & 0.1236 & 0.1310 & 0.1095 & 0.1128 & 0.1667 & 0.1598 & 0.1720 & 0.1606 \\
\hline \multirow[t]{2}{*}{ 2-firm cartel } & 0.3605 & & 0.2792 & & 0.4480 & & 0.3523 & \\
\hline & 0.1150 & & 0.1203 & & 0.1025 & & 0.1206 & \\
\hline \multirow[t]{2}{*}{ 3-firm cartel } & 0.0426 & -0.2596 & -0.0780 & -0.3121 & 0.2583 & -0.1181 & 0.0896 & -0.2064 \\
\hline & 0.1357 & 0.1090 & 0.1463 & 0.0963 & 0.1437 & 0.1244 & 0.1521 & 0.1252 \\
\hline \multirow[t]{2}{*}{ 4-firm cartel } & -0.0154 & -0.3252 & -0.1066 & -0.3466 & 0.0771 & -0.3077 & -0.0374 & -0.3400 \\
\hline & 0.1627 & 0.1380 & 0.1713 & 0.1239 & 0.2047 & 0.1713 & 0.2218 & 0.1858 \\
\hline Number of obs. & 31 & 31 & 31 & 31 & 29 & 29 & 29 & \\
\hline R squared & 0.404 & 0.327 & 0.531 & 0.489 & 0.439 & 0.365 & 0.541 & 0.499 \\
\hline t-statistic 2-firm=3-firm & 3.26 & & 4.06 & & 1.48 & & 1.95 & \\
\hline t-statistic 3-firm=4-firm & 0.55 & & 0.31 & & 1.05 & & 0.46 & \\
\hline
\end{tabular}

Robust standard errors are in italics. Coefficients that are significant at the $5 \%$ level are in bold.

Focusing on regressions $1-4$, we see statistically significant coefficients for a twofirm cartel's price increase and for the price decreases of three and four-firm cartels. The coefficient for a two-firm cartel is significantly different from that for a threefirm cartel, but the coefficients for three and four-firm cartels are not significantly different from one another. The results for regressions 5-8 again show a positive significant coefficient on the two-firm dummy. The coefficients on the cartel dummies are generally larger in regressions 5-8 than in regressions 1-4, which may reflect collusive behavior prior to the beginning of the plea period as suggested by the results of Marshall, Marx, and Raiff (2005).

In the second set of regressions, we focus on price changes relative to the last month of the plea period. This dependent variable allows us to focus on the sustainability of the collusive price increase. 
Table 7: Regressions 9-12

\begin{tabular}{|c|c|c|c|c|}
\hline Regression Number & 9 & 10 & 11 & 12 \\
\hline \multirow{3}{*}{\begin{tabular}{|l} 
Dependent Variable \\
constant
\end{tabular}} & \multicolumn{2}{|c|}{$\begin{array}{c}\% \text { change in price at } \\
+12 \text { relative to last } \\
\text { month of plea }\end{array}$} & \multicolumn{2}{|c|}{$\begin{array}{c}\% \text { change in price at } \\
+24 \text { relative to last } \\
\text { month of plea }\end{array}$} \\
\hline & 0.0308 & 0.0215 & 0.0790 & 0.0157 \\
\hline & 0.0593 & 0.0234 & 0.0558 & 0.0242 \\
\hline \multirow[t]{2}{*}{ feed } & -0.0895 & -0.0898 & -0.0879 & -0.0900 \\
\hline & 0.0646 & 0.0635 & 0.0626 & 0.0618 \\
\hline \multirow[t]{2}{*}{ non-cartel share $[5,10)$} & -0.0365 & -0.0339 & -0.0737 & -0.0558 \\
\hline & 0.0497 & 0.0415 & 0.0485 & 0.0414 \\
\hline \multirow[t]{2}{*}{ non-cartel share $>=10$} & -0.2031 & -0.2021 & -0.2500 & -0.2432 \\
\hline & 0.0482 & 0.0485 & 0.0446 & 0.0468 \\
\hline \multirow[t]{2}{*}{ 2-firm cartel } & -0.0098 & & -0.0665 & \\
\hline & 0.0475 & & 0.0455 & \\
\hline \multirow[t]{2}{*}{ 3-firm cartel } & -0.0591 & -0.0509 & -0.1634 & -0.1077 \\
\hline & 0.0776 & 0.0491 & 0.0739 & 0.0480 \\
\hline \multirow[t]{2}{*}{ 4-firm cartel } & -0.0623 & -0.0539 & -0.1535 & -0.0963 \\
\hline & 0.0888 & 0.0682 & 0.0865 & 0.0674 \\
\hline Number of obs. & 31 & 31 & 31 & 31 \\
\hline R squared & 0.626 & 0.626 & 0.752 & 0.746 \\
\hline t-statistic 2-firm=3-firm & 1.05 & & 2.14 & \\
\hline t-statistic 3-firm=4-firm & 0.05 & & -0.17 & \\
\hline
\end{tabular}

Focusing on regressions 9-12, we see that having a non-cartel production share greater than $10 \%$ results in a statistically significant decrease in the price during the twelve months after the end of the plea period. In regressions 11-12, the coefficient for the three-firm cartel is negative and statistically significant. Also in these regressions, the coefficients on two-firm and three-firm cartels are significantly different, but the coefficients for three and four-firm cartels are not significantly different from one another.

Considering the regressions of Tables 6 and 7 together, the feed dummy appears to be of no consequence. We expect the dummy for the non-cartel production share to capture both entry and competitive effects in regressions $1-8$. The high price during the explicitly collusive period would be expected to induce entry, possibly causing the post-plea price to fall below its pre-plea levels (the entry effect), and a larger noncartel share would be expected to increase the rate at which the price declines after the end of explicit collusion (the competition effect). In regressions 9-12, we expect these dummies to capture only competitive effects because in these regressions the percentage change is not measured relative to pre-plea levels. The regression results suggest that the competitive effects are more important.

The large positive and statistically significant coefficients on the two-firm cartel dummies in the regressions in Table 6 imply that a two-firm cartel achieves a larger increase in price during the plea-period than when there is a monopoly producer. One might interpret this as occurring because products in which there was a monopoly 
producer were already priced at monopoly levels. The two-firm cartel dummies are not significant in the regressions of Table 7 because prices are equally persistent relative to a monopoly.

The three and four-firm cartel dummies in regressions 1-4 suggest that prices for three and four-firm cartels are approximately 30\% lower than for a one or two firm cartel, relative to their pre-plea levels. One reason that the three and four-firm dummies are not always significant is that there is a positive correlation between the non-cartel share and the number of firms in the cartel. Finally, note that we see significant coefficients on the three-firm cartel dummy in regressions 11 and 12, but not in regressions 9 and 10, which reflects the continuing erosion in price following the end of the plea period.

\subsection{Role of a Maverick Firm}

As suggested by the Horizontal Merger Guidelines, the presence of certain firms, labeled "mavericks," in an industry may reduce the ability of the other firms to maintain prices above their competitive levels. In the Vitamins Industry, twelve firms paid a total of $\$ 911$ million in fines related to U.S. antitrust charges; however, Rhone-Poulenc, who was a producer of a Vitamin A and E products, received amnesty and did not pay any U.S. fines. ${ }^{20}$

\footnotetext{
${ }^{20}$ Roche, BASF, Takeda, Eisai, Daiichi, and Merck, which were major manufacturers of the vitamin products in our data, all paid substantial U.S. fines. Besides Rhone-Poulenc, the only cartel firms for vitamin products in our data that did not pay U.S. fines were Solvay (Vitamin D), Kongo (Folic Acid), and Sumika/Sumitomo (Folic Acid).
} 


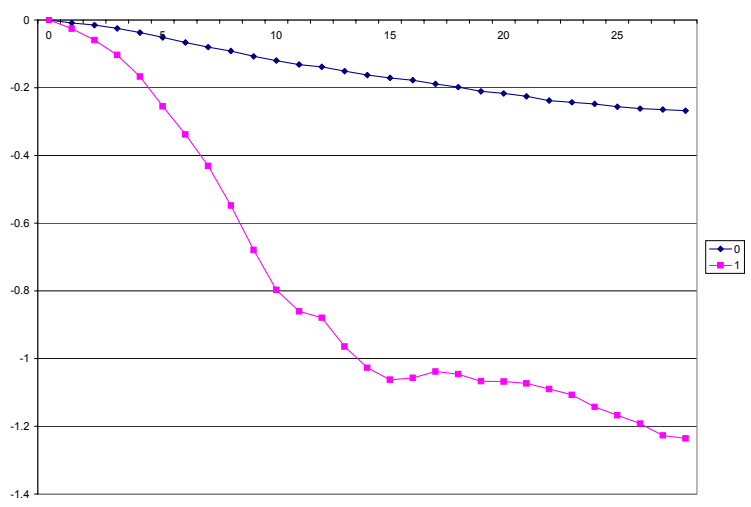

Figure 9: Average percentage change in price relative to the last month of the plea period by participation by Rhone-Poulenc ( 0 indicates Rhone-Poulenc did not produce the vitamin product and 1 indicates that it did). Date zero is the last month of the plea period, and positive dates indicate months after the end of the plea period.

The conditions of amnesty might have induced behavior by Rhone-Poulenc so that it acted like a maverick firm in this industry during the post-plea period. To analyze this conjecture, we run two additional regressions. We consider how the presence of Rhone-Poulenc affects the percentage change in price one year and two years after the end of the plea period, relative to the last month of the plea period.

Table 8

\begin{tabular}{|lcc|}
\hline Regression number & 13 & 14 \\
\hline Dependent Variable & $\begin{array}{c}\text { \% change in price at }+24 \\
\text { relative to last month of plea }\end{array}$ & $\begin{array}{c}\text { \% change in price at }+12 \\
\text { relative to last month of plea }\end{array}$ \\
\hline constant & -0.0146 & 0.0394 \\
feed & 0.0383 & 0.0423 \\
non-cartel share $[5,10)$ & 0.0331 & 0.0191 \\
& 0.0322 & 0.0429 \\
non-cartel share $[10,100]$ & 0.0089 & -0.0341 \\
& 0.0194 & 0.0315 \\
2-firm cartel & -0.1615 & -0.2136 \\
& 0.0363 & 0.0401 \\
3-firm cartel & 0.0056 & -0.0531 \\
& 0.0358 & 0.0361 \\
4-firm cartel & -0.0461 & $-\mathbf{0 . 1 5 2 1}$ \\
Rhone-Poulenc & 0.0424 & 0.0499 \\
& -0.0443 & $-\mathbf{0 . 1 3 7 8}$ \\
Number of obs. & 0.0586 & 0.0665 \\
R squared & -0.3303 & -0.2884 \\
obust standard errors are in italics. Coefficients that are significant at the 5\% level are in bolk & & 0.0577 \\
\end{tabular}


As shown in Table 8, the coefficient on the Rhone-Poulenc dummy is negative and highly statistically significant. In addition, it is large in magnitude, dwarfing all other effects in the first regression. The point estimates in the second regression show that having a non-cartel production share of greater than $10 \%$ results in a $21 \%$ decrease in the price in the first two years after the end of the plea period, but the presence of Rhone-Poulenc results in a $29 \%$ decrease in price over the same period, all else constant.

So, the post-plea behavior of Rhone-Poulenc, which is reasonably conjectured to be induced by the conditions of amnesty, provides a window by analogy to the impact of maverick firm on pricing behavior in an industry.

\section{Conclusion}

As we mentioned in the introduction, there are papers in the economics literature that attempt to answer the question of how many is enough for competition. Returning to this question, our data show that, at least for the Vitamins Industry, two is clearly not enough for competition. As for three or four, it is not clear from our data whether

having three or four firms in a market is sufficient to guarantee the competitive outcome, but our data do suggest having three or four firms results in a significantly more competitive outcome than having only two firms in the market.

Although it is difficult to extrapolate to other industries, the evidence from the Vitamins Industry suggests that a proposed reduction in the number of firms manufacturing a given product from four to three via a merger does not alone pose an incremental threat in terms of tacit coordination. But, this should not be interpreted as blanket approval for mergers in which industry size goes from four to three. The vitamins product data suggests that the real social danger after a period of explicit collusion is duopoly, and three is much closer to two than four. Coordinated effects analysis would be required of any merger to assess whether the merger will lead the industry toward effective duopoly through tacit (or explicit) collusion.

Beyond its specific technical findings, our examination of the Vitamins Cartel suggests the value of retrospective inquiries as guides to the refinement and application of coordinated effects analysis to the review of mergers. Amid continuing debate about how competition authorities should conduct a coordinated effects analysis and about whether the treatment of coordinated effects in the U.S. merger guidelines 
requires adjustment, there appears to be broad agreement about the value of using retrospective studies to supplement a careful fact-intensive assessment of proposed transactions and the institutional arrangements that govern the operations of the merging parties (FTC/DOJ Joint Workshop 2004, 127-195). Merger policy will be well served if enforcement authorities continue the modern practice of investing resources in research programs to gather and analyze post-merger data and to tap their experience in investigating and prosecuting cartels. 


\section{References}

Bain, Joe S. (1951), "Relation of Profit Rates to Industry Concentration," Quarterly Journal of Economics 55, 293-324.

Baker, Jonathan B. (2004), "Efficiencies and High Concentration: Heinz Proposes to Acquire Beech-Nut (2001), in The Antitrust Revolution (John E. Kwoka, Jr. and Lawrence J. White, eds.), 150-69.

Baker, Jonathan B. (1993), "Two Sherman Act Section 1 Dilemmas: Parallel Pricing, the Oligopoly Problem, and Contemporary Economic Theory," Antitrust Bulletin 38, 143.

Bernheim, B. Douglas (2002), Expert Report of B. Douglas Bernheim, M.D.L. No. 1285, In Re: Vitamins Antitrust Litigation, Misc. No. 99-0197 (TFH), May 24, 2002 .

Bresnahan, Timothy F. and Peter C. Reiss (1991), "Entry and Competition in Concentrated Markets," Journal of Political Economy 99, 977-1009.

Chamberlin, Edward H. (1933), The Theory of Monopolistic Competition, Cambridge, Mass.: Harvard University Press.

Dolbear, F. T., L. B. Lave, G. Bowman, A. Lieberman, E. Prescott, F. Rueter, and R. Sherman (1968), "Collusion in Oligopoly: An Experiment on the Effect of Numbers and Information," Quarterly Journal of Economics 82, 240-259.

Federal Trade Commission (Feb. 2, 2004), "Horizontal Mergers Investigation Data, Fiscal Years 1996-2003)." Available at http://www.ftc.gov/os/2004/08/040831 horizmergersdata96-03.pdf.

Federal Trade Commission and Department of Justice (Feb. 18, 2004), Transcript of FTC/DOJ Joint Workshop on Merger Enforcement. Available at http://www. ftc.gov/bc/mergerenforce/040218ftctrans.pdf.

Gavil, Andrew I., William E. Kovacic and Jonathan B. Baker (2002), Antitrust Law in Perspective: Cases, Concepts and Problems in Competition Policy, St. Paul, MN: West Publishing.

Gellhorn, Ernest, William E. Kovacic and Stephen Calkins (2004, 5th Edition), Antitrust Law and Economics in a Nutshell, St. Paul, MN: West Publishing.

Greene, Hillary (2005), "Agency Character and the Character of Agency Guidelines: An Historical and Institutional Perspective," Antitrust Law Journal 72, 103956. 
Huck, Steffen, Hans-Theo Normann, and Jörg Oechssler (2004), "Two are Few and Four are Many: Number Effects in Experimental Oligopolies," Journal of Economic Behavior \& Organization 53, 435-446.

Kaysen, Carl and Donald F. Turner (1959), Antitrust Policy: An Economic and Legal Analysis, Cambridge, MA: Harvard University Press.

Kolasky, William J. (Apr. 24, 2002), "Coordinated Effects in Merger Review: From Dead Frenchmen to Beautiful Minds to Mavericks." Available at http://www. usdoj.gov/atr/public/speeches/11050.htm.

Kovacic, William E. (2003), "The Modern Evolution of U.S. Competition Policy Enforcement Norms," Antitrust Law Journal 71, 377-478.

Kovacic, William E. (2005), "Measuring What Matters: The Federal Trade Commission and Investments in Competition Policy Research and Development," Antitrust Law Journal 72, 861-69.

Kovacic, William E. (1989), "Failed Expectations: The Troubled Past and Uncertain Future of the Sherman Act as a Tool for Deconcentration," Iowa Law Review $74,1105-50$.

Kovacic, William E. and Carl Shapiro (2000), "Antitrust Policy: A Century of Economic and Legal Thinking," Journal of Economic Perspectives 14, 43-60.

Kwoka, John E. (1979), "The Effect of Market Share Distribution on Industry Performance," Review of Economics and Statistics 61, 101-109.

Leary, Thomas B. (2002), "The Essential Stability of Merger Policy in the United States," Antitrust Law Journal 70, 105-142.

Muris, Timothy J., and Robert Pitofsky (2005), "More than Law Enforcement: The FTC's Many Tools - A Conversation with Tim Muris and Bob Pitofsky," Antitrust Law Journal 72, 773-860.

Robert C. Marshall, Leslie M. Marx, and Matthew E. Raiff (2005), "Cartel Price Announcements: The Vitamins Industry," Working Paper, Duke University.

Selten, Reinhard (1973), "A Simple Model of Imperfect Competition, Where 4 Are Few and 6 Are Many," International Journal of Game Theory 2, 141-201.

Stigler, George (1964), "A Theory of Oligopoly," Journal of Political Economy 72, $44-61$.

Symposium (2003), "The 20th Anniversary of the Department of Justice 1982 Merger Guidelines," Antitrust Law Journal 71. 
Werden, Gregory J. and Michael G. Baumann (1986), "A Simple Model of Imperfect Competition in which Four are Few but Three are Not," Journal of Industrial Economics 34, 331-335. 